\title{
POST-SOCIALIST URBAN TRANSITIONS AND TRANSFORMATIONS, THE CASE OF THE CITY OF INĐIJA, SERBIA
}

DOI: https://doi.org/10.18509/GBP210181gj

UDC: $316.334 .56(497.11)$

\author{
Bojan Đerčan \\ Milka Bubalo Živković \\ Tamara Lukić \\ Dajana Bjelajac \\ Zorica Pogrmić
}

Department of Geography, Tourism and Hotel Management, Faculty of Sciences, University of Novi Sad, Serbia

\begin{abstract}
The cities and their centers, as the most relevant indicators of events and conditions in the society, during the transition period suffered a significant identity crisis, which followed not only as a result of new cultural and ethical patterns of living and participating in the use of the urban environment, but as a result of numerous conflicts and manipulation of public space. Significant social, cultural and spatial changes have taken place in this settlement, and on this occasion the emphasis will be on spatial transformations. Over the last few years, Inđija has been developed and built at high speed. Foreign investors, attracted by the good location of the settlement, invest in this town and many factories are being opened. Industrial zones are being upgraded and industry is being developed. The city increasingly supports culture and education. Spatial transformations have affected both the central parts of the city and the urban periphery. There was a transformation of residential into a commercial space, but also the construction of new, modern business premises. Single-family housing units in central parts of the city are increasingly being replaced by collective housing facilities, while at the same time the number of single-family housing units is being increased on the outskirts of the city.
\end{abstract}

Keywords: post-socialist transition, urban challenges, transformation, Inđija, Serbia

\section{INTRODUCTION}

The most influential and well-known international academic debate on cities in socialist countries emerged in 1980, and this is strongly linked to the French and Hamilton's publication Socialist City: Spatial Structures and Urban Policies [1], and with a large number of scientific articles written by scholars from Central, Eastern and Western Europe [2-14].

In European socialist countries, much has been written about the principles that should trace socialist urbanism and architecture, especially in specialized journals and publications, and many ideas have been adopted from Soviet literature and practice [15]. Here, a socialist city, often opposed to or compared to the capitalist pendant and capitalist urban development, is defined as the rule. This is not, however, a mandatory conception for academic papers written by urban geographers and sociologists.

For example, Hahn and Kahl [16] described socialist cities as cities with particular patterns of functional and class differentiation, corresponding to the historical situation and the past. Matějů [17] used the socialist city category in his analysis of the socio- 
spatial structure of Prague. He understood that the structure of a socialist city should reflect new "socio-economic conditions" and a "socialist way of life," and that it should be different from the previous, pre-socialist period [17].

Western authors also tried to study cities in the Soviet Union and in the socialist countries of the time. During the 1950s and 1960s, they first wrote about the "Soviet city," which depicts typical features of cities in the Soviet Union, often reflecting on the consequences of socialist planning principles [18-19]. In later works about European socialist countries, the term "Socialist city" appeared, and the category "Soviet city" or "Soviet socialist city" continued to exist [20]. Thus, for example, Fisher [21] wrote about the theories and principles of planning in a socialist city, as well as their actual implementation and results in the field.

After 1989, attention turned to the analysis of post-socialist cities, showing in particular the processes of rapid change. The socialist era began to be seen primarily as an important episode in history, which established the particularities of these cities in the form of a slow-abandoning heritage. Some conceptualizations of socialist cities have continued in the scientific literature. Smith [22] reiterated the question of the existence of a socialist city as an essential alternative to a capitalist city, and considered the features of the spatial structure that actually call for a comparison of the socialist city with those of Western Europe and North America: general physical organization, socio-economic differentiation, and ethnic segregation. Haussermann [23] explained the characteristics of a socialist city by comparing it to a capitalist one. Other authors have suggested spreadsheets of characteristics of socialist cities [24], their spatial characteristics [25], or models of investment patterns [26], which are then compared not with the capitalist city but with the post-socialist urban changes.

From global perspective, international, national, and local policies since the beginning of the last decade of the twentieth century, as well as the path of dependence based on the communist past, have exerted a tremendous influence on post-communist urban development. Such circumstances have led to an extremely high rate of reform in many areas: privatization of social housing, property restitution, commercialization of city centers, decentralization of housing and retail space under new market conditions, and reforms in public infrastructure investments [27].

Notwithstanding the differences of urban context in countries in transition, one common characteristic is quite easy to spot. The post-communist tradition, over the past twenty years, has had a profound impact on the lives of over 400 million inhabitants of the Balkans, Eastern Europe and the former Soviet Union (Albania, Azerbaijan, Belarus, Bosnia and Herzegovina, Bulgaria, Montenegro, Czech Republic, Estonia, Georgia, Croatia, Armenia, Kazakhstan, Kyrgyzstan, Latvia, Lithuania, Hungary, Macedonia, Moldova, Poland, Romania, Russia, Slovakia, Slovenia, Serbia, Tajikistan, Turkmenistan, Ukraine, Uzbekistan). The fact that two-thirds of the population of these countries live in cities justifies the accentuated treatment of cities as major drivers of economic growth during the communist period.

During the early 1990s, many countries in the region experienced a steep decline in living standard, with unemployment rising to as much as a quarter of the population, with expansion and inflation reaching three-digit values. The removal of the state government in almost all communist countries was accompanied, necessarily, by emergency conditions with strong security measures. Restarting the economy posed a huge challenge given the difficult legacy of outdated and inefficient industrial enterprises. The position of residents visibly aggravated by the erosion of personal purchasing power has led to the 
collapse of domestic demand, which in turn has led to a sharp decline in investment activities [27].

The implementation of reforms in the 1990s showed significant differences between countries in the region. This result can be explained by the different ways they developed historically. The disintegration of the Soviet Union as a country under the strongest centralized communist influence caused greater challenges and demands for its newly created states than in the countries of Central and Eastern Europe [28], which had a relatively greater degree of economic independence during the communist period, greater potential and a willingness to experiment with marketing-oriented reforms. Countries such as the SFRY and Hungary began their free-market attempts in the 1970s, which continued into the 1980s. However, the progress of some countries in the region has been slowed by the explosion of ethnic wars and conflicts. This has also happened in Serbia, where after the breakup of the old regimes, internal national consolidation and interstate cooperation in these subregions were prevented, and this type of cooperation is actually one of the important factors and bases for a new economic regeneration and speedy recovery [29].

The level of foreign investment received by post-communist countries since the beginning of the transition process has further widened the gap between them. With foreign investment, variations in the pace of economic recovery are closely related to the different historical legacies of the countries. Countries that are both spatially and traditionally closer to a prosperous European Union have benefited significantly from their neighbors, not only in the post-communist years, but throughout modern history. The links that they have made with them through trade and cultural exchange for centuries have been further strengthened since 1989. The experience of transition has shown that the greatest progress has been made by those countries in which state institutions have become directly involved in planning and coordinating the development of global competition in order to attract new foreign investment [27].

As the city is one of the most important spatial pillars of globalization, its consequences have manifested themselves very quickly. Globally, there has been a process in which major cities and large metropolitan areas have drawn secondary and tertiary cities towards themselves in the urban hierarchy, resulting in a slower pace of economic restructuring in smaller cities, towns and villages in transition. This particularly affected all the communist cities, which were planned as centers of certain industries and, on the basis of that production, were the leading centers of their region. With the shutting down of these industrial plants, these lower-level settlements inevitably struggle to find their market opportunities, the so-called niches, in the global investment competition. In such a situation, these settlements faced a future dependence on the financial initiative and, as a rescue solution, they received financial support from the European Union, in the form of various funds.

As a result of external and internal economic, political and cultural factors, a process of urban space restructuring has also taken place. These processes have led to a great number of negative, but also to a number of positive shifts. One of the most significant achievements of the transition period is the sudden increase in the rate of property owners among the population. This process was used as a "shock absorber" to reduce the negative social impacts of the transition period. On the plus side, after two decades of housing reform, residents were offered a greater variety of housing options, including multi-storey buildings, self-contained flats, row houses, and single villas on parcels in suburban neighborhoods, which particularly suited the more affluent sections of society. In this 
way, the new housing construction clearly oriented the directions of future development of residential zones and enabled the release of more commercial space in urban centers [30].

Similar processes have affected the non-residential part of the real estate market. In this case too, affluent firms were given the opportunity to choose from a variety of locations, from commercial office spaces and outlets in exclusive city centers, to suburban businesses and retail shopping parks on the outskirts. At the same time, entrepreneurs from the lower classes were given shelves for outdoor trade and redesigned basements and garages.

In addition, there was a significant decline in public service delivery, as construction and reconstruction of public infrastructure and utilities remained on hold for some other better times. Secondly, the privatization process should not only be about taking over the leadership of the economy and the housing sector, but should also be interspersed with the public sector at all levels, which included aggressively appropriating public space for a wide range of private needs and satisfying the appetite of numerous private interests. Erasing the open spaces, small urban parks and large green pieces of urban infrastructure from the face of urban landscape on a daily basis have become a hallmark of spatial changes in the post-communist period. The public interest, as a category that strives for the quality-of-life conditions of citizens, has been made available to the market as the main regulator of change. Privatization became the leitmotif of the transition period. Also, aggressive takeover of public space (streets, squares) by allocating oversized areas for parking of citizens' private vehicles has led to further degradation of functional use of urban space, especially in the central urban area, which often left city centers isolated from their users [30].

Undoubtedly, urban restructuring has been imposed as an inevitable step towards the goal of achieving a modern democratic order, but its consequences have left a clear mark on the spatial potential of most cities, which in the coming period will need to invest a lot of knowledge and money to return to the real and a sustainable path.

The socialist socio-economic system has failed to create a post-industrial city. Namely, since the 1970s, there has been a restructuring of economic and social life in major urban centers in developed societies due to the emergence of post-industrial society. The postindustrial city is characterized by de-industrialization, changes in production structure, labor market and professional structure. The secondary sector is declining, the tertiary and, in particular, the quaternary sector is growing rapidly. There is a shift from production of goods to the development of the service sector. These changes in the economy have also brought about changes in the nature of the need for real estate, the increasing demand for the office space, space for shops, hotels, light industry, storage, and more [31].

Has the post-socialist transformation had spatial consequences? An increase in the level of urbanization could be expected due to the restructuring of the economy and a decrease in the rural population. Socio-political differentiation has gradually led to socio-spatial segregation, through the process of suburbanization, the relocation of middle and upper classes to the outskirts of the city, or the process of gentrification, urban redevelopment of inner urban areas, into which members of higher social groups move in with the displacement of their previous poor inhabitants.

The consequence of socialist urban policy, on the one hand, was the homogenization of the city's socio-ecological structure, and on the other, the underutilization of space in prestigious places in the inner city. Commercial space is part of a "built environment" 
that clearly shows the difference in land use in a socialist and capitalist city. The central parts of large capitalist cities are highly commercialized and housing functions very limited, while socialist cities are characterized by a lower level of business and retail space and a higher share of downtown housing. Differences are also evident in the suburbs of these cities. In general, retail was underdeveloped during socialism, with existing stores located in the city center, while in the suburbs the development of retail stores lagged behind in housing construction [31].

The redistribution of the existing commercial space took place in the first years of transition, and there was a transformation of the residential space into a commercial one. The general lack of commercial space, especially high quality one, led to the construction of new commercial buildings. Initially, business premises were the ones most often built, but later retail and storage facilities and light industry started being built as well. Demand first came from start-ups, in the mid-1990s, existing companies expanded, and then sought a much larger space with good traffic links, which could also be outside central areas, thus beginning the process of suburbanization of commercial content.

The retail sector has undergone radical changes in its spatial structure in the 1990s. Lower order sales e.g., vegetable and grocery stores have been squeezed out of the center, with exclusive shops, which can pay a high rent, opening in their place. The result of this is the city center becoming a specialized shopping area. The novelty is the emergence of street commerce among residential blocks and along major streets. For many citizens of the post-socialist city, their experience of capitalism is linked to street sales and the informal economy [32].

Opening borders has led to a sharp rise in trade in post-socialist cities. EU Countries or candidates for admission to the EU and EU bordering countries are trying to institutionalize the exchange more and more. The successful privatization of retail in these countries has suppressed street commerce, thus it plays a small role. In countries with major economic problems, it continues to be a substitute for the failing retail sector. The highlight of the development of the retail sector is the construction of large shopping centers, the entry of international retail chains into post-socialist countries [31].

\section{GEOGRAPHICAL POSITION OF THE RESEARCH AREA}

The Municipality of Inđija is located in the northeast of Srem District. It covers the area of $386 \mathrm{~km}^{2}$. The geographical location of Inđija is favourable, both from natural and anthropogeographic point of view. Natural factors contribute to the favourable location, as the settlement was erected on the woodland plateau and in the valley of the Indija stream.

Anthropogeographic factors contribute mostly for traffic reasons. The city was built next to the roads connecting Novi Sad and Belgrade (highway and railway). It is $35 \mathrm{~km}$ away from Novi Sad and $40 \mathrm{~km}$ from Belgrade (Figure 1). The gravitational pull is felt from both cities. Belgrade's influence was strengthened after the construction of the Novi SadBelgrade highway. Administratively, it represents the central settlement of the Municipality and is connected with all municipality's settlements by local roads.

Indija is the only urban settlement in the territory of the Municipality. The altitude of the city is $113 \mathrm{~m}$. The coordinates of Inđija are $45^{\circ} 03^{\prime}$ northern latitude and $20^{\circ} 05^{\prime}$ eastern longitude. 


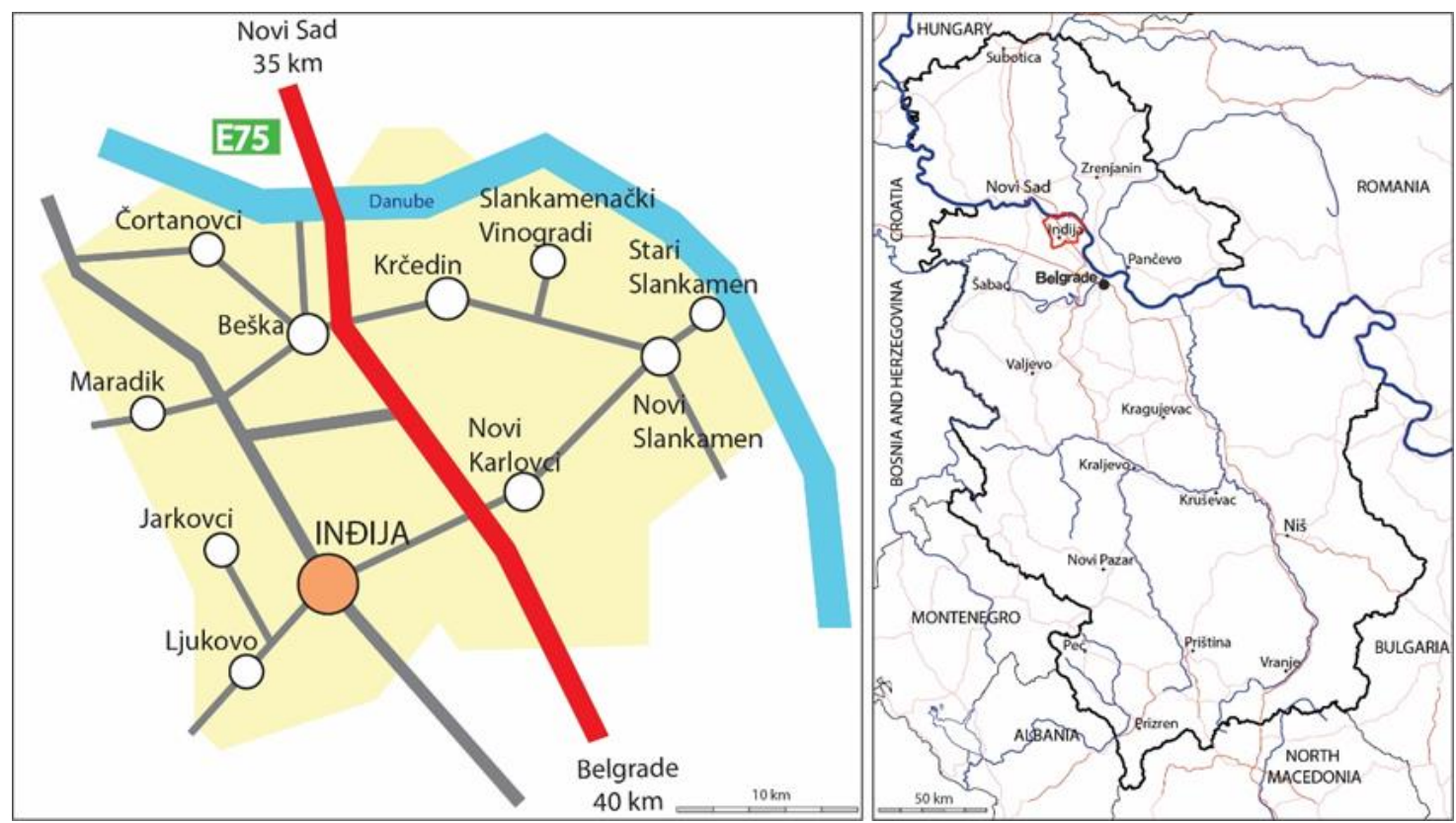

Figure 1: Geographical position of the research area.

Source: author's processing

\section{SPATIAL TRANSFORMATIONS OF INĐIJA DURING THE TRANSITION PERIOD}

The gravitational influences of Novi Sad and Belgrade are strongly felt in the area of Inđija. Inđija took advantage of these circumstances, so that, above all, craft and trade functions are represented here, which are largely in the service of the economies of these cities. All other city functions are represented as average for central places [33].

Over the last few years, Inđija has been developed and built at high speed. Foreign investors, attracted by the good location of the settlement, invest in this town and many factories are now being opened. Industrial zones are being upgraded and industry is being developed. The town increasingly supports culture and education. The reconstruction of the road network, the elimination of water supply problems, the development of agriculture, etc., are underway.

In the process of transition, the structure of economic entities in the economy of Indija has significantly changed both in terms of activities and number and size of the business societies. Traditional activities, which were the bearers of economic activities until the year 2000, practically ceased to exist during this process (textile industry, leather processing, furniture production, production of rubber profiles, etc.) or survived only in the field of entrepreneurial economy.

With a new, strong investment cycle in Inđija factories have been opened, mainly by foreign investors, in completely new industries, such as cigarette production, auto parts manufacturing, meat processing, production of LPG equipment, battery recycling, production of brand new materials for the construction industry, new service activities, as well as the construction of facilities in the area of trade - new types of shopping and business centers with facilities that significantly improve the living conditions of all citizens of Inđija.

Today, the economy of Inđjija is dominated by small and medium-sized enterprises, which are much more flexible when it comes to meeting the challenges of a market economy, which has made the effects of the global economic crisis reflecting on their 
business operations to be minimal. There are over 2,000 businesses - over 1,500 entrepreneurs and about 600 companies. They are mostly greenfield investments, while there are also brownfield investments.

The largest investor in the municipality of Inđija is the Danish Grundfos, a pump and compressor production company, with an investment value of $€ 50$ million, followed by the Fashion Park Outlet Center of the British company Black Oak Developments (initial investment of $€ 25$ million). $€ 21$ million investments were made by Metal Cinkara from Slovenia and Energoselen, a modern Category 1 animal waste processing plant owned by Greenworx Holding (51\%), Saffelberg Investments (37\%) and Ecotech Solutions (12\%) [34].

Also, worth mentioning here is the arrival of the Indian company Embassy Group, which has built the first phase of an IT facility, Park IT, in Inđija, with an initial investment value of $€ 15$ million. There are also "Thyssen Krupp" from Germany (12 million euros), "Terraproduction" from Serbia (11 million euros), while 8 million investments are made by "Henkel" from Germany and "Farmina Pet Foods" from Italy. Another Italian company for the production of concrete products intended for construction, which has been operating successfully since 2010, is Martini gradnja, whose investment amounted to 6 million euros [34].

The German company "IGB Automotive" which deals with the production of electronic and electrical equipment for motor vehicles, has the greatest number of employees. In 2007, the company's investment amounted to $€ 11$ million. Since then, this investor has built and enlarged its own production facilities and today has over 1,200 employees, 90\% of which are women [34].

One of the latest investments in the series is made by the Indonesian company Indoadriatic Industry engaged in the production of noodles under the license of "Indofood". The value of this investment is $€ 11$ million [34].

Inđija has two fully functional, communally equipped industrial zones, which place Inđija at the very top of the Serbian offer in terms of potential and attractiveness for investing. Most of the new facilities are located in the northeastern industrial zone.

The formation of industrial zones enabled the construction of new capacities, as well as the possibility of permanent dislocation of all production capacities from the central and residential part of the settlement, which is primarily reflected in the quality of the environment in the settlement, as well as the quality of working and production conditions. In this way, industrial zones are clearly differentiated, being the most striking spatial transformations that Inđija experienced (and still experiences) during the period of transition. The northeastern and southeastern suburbs are now made up of factory complexes, which are clear benchmarks in the area, giving these parts of the town a specific character and a distinctive external physiognomy of the settlement.

One of the features of the transition period is the construction of out-of-town shopping centers. Such facilities include outlet centers, often designed as small towns. Designed as places to sell wardrobes from previous seasons, with constant sales, with accompanying leisure and recreation facilities, and counting on longer visitor retention, outlet malls should not compete with downtown shopping malls. Fashion Park Outlet Center Inđija is the first shopping destination of its kind in Serbia. The first outlet center in Serbia is the BlackOak Developments project. The Fashion Park Outlet Center in Inđija is an integral part of the planned Retail Park, a 60-hectare complex that will consist of a hotel, an aqua park and a logistics center [35]. This complex has a very good traffic position because it is located in the northeastern industrial zone, next to the E-75 route, easily accessible for 
the residents of Belgrade and Novi Sad, as well as buyers from other parts of Serbia.In addition to the visible transformations of the urban periphery in the form of industrial zones, changes have taken place in the central parts of Inđija since the 1990s.

At the beginning of the transition period, the growth of the tertiary and quaternary sectors was noticeable. The service sector needed office space, shops, warehouses, light industry facilities. As a result of the rapid demand for new office space, a transformation of residential areas into commercial ones occurred. Such transformations are most visible in the central streets of Inđija - Kralja Petra I Karađorđevića Street, Novosadska Street, Vojvode Stepe Street and Cara Dusana Street.

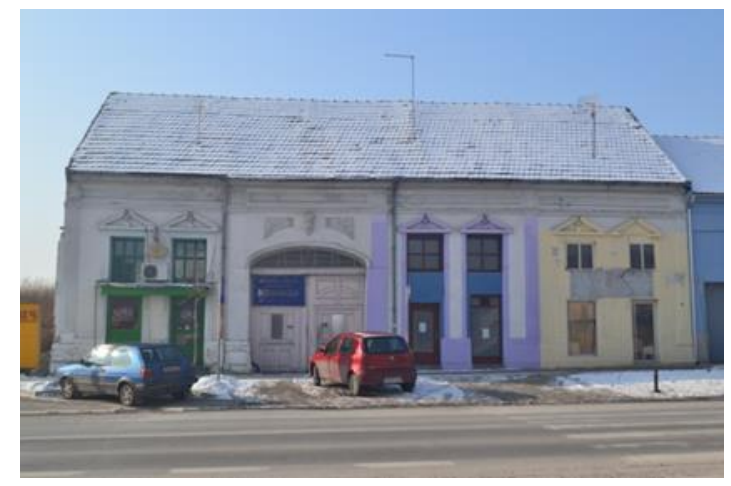

Figure 2. Examples of converting a residential area into a commercial one in King Peter Street. Source: author's archive

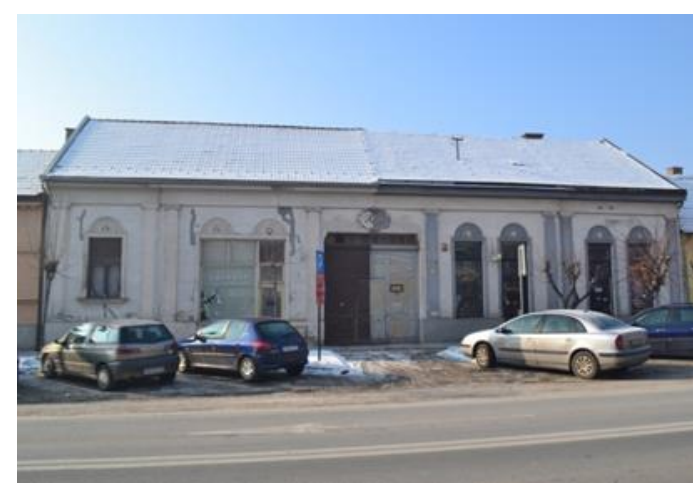

Figure 3. Examples of converting a residential area into a commercial one in King Peter Street. Source: author's archive

The lack of high-quality commercial area has influenced the construction of new office buildings. One of the first buildings erected is Sloboda Mall in the center of Indjija. Today it houses numerous banks, insurance companies, shops, cafes.

Apart from that, buildings have been built in central city streets, especially since 2000, combining work and housing functions. Most often, these are multi-family residential buildings, up to five floors high, the lower floors of which house banks, shops, bakeries and various other facilities.

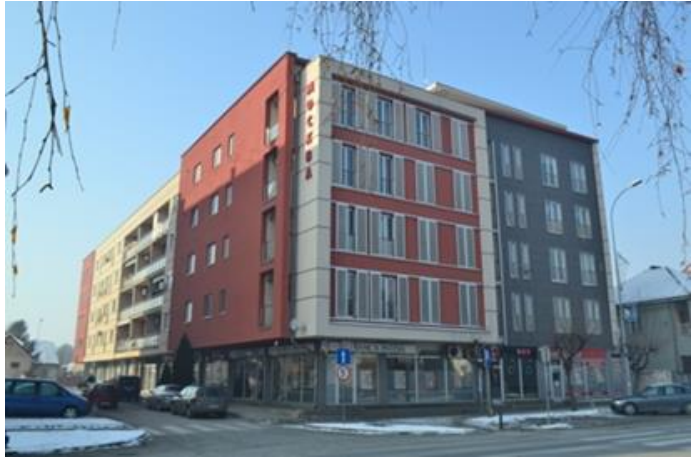

Figure 4. New construction in central parts of the city. Source: author's archive.

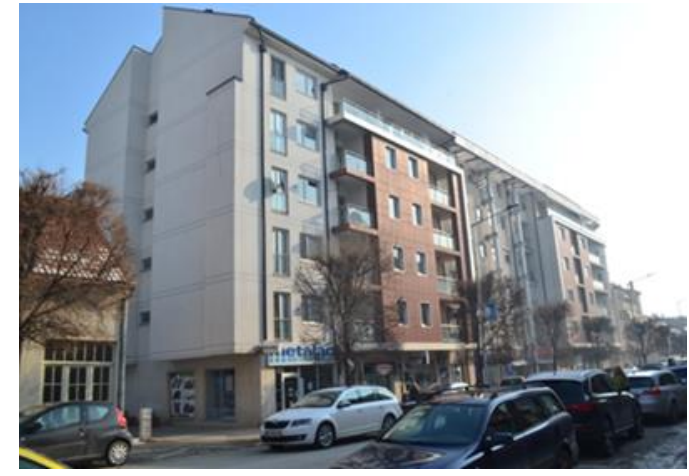

Figure 5. New construction in central parts of the city/ Source: author's archive

The pinnacle of development of the retail sector in postsocialist cities is the construction of large shopping centers. One good example of a more recent date is the Tradeunique City Shopping Center, built on the corner between Vojvode Stepe and Dušan Jerković Streets. The complex covers an area of 50,000 m2, including a megamarket, boutiques, cafes, administrative and commercial premises, underground garage [36]. 


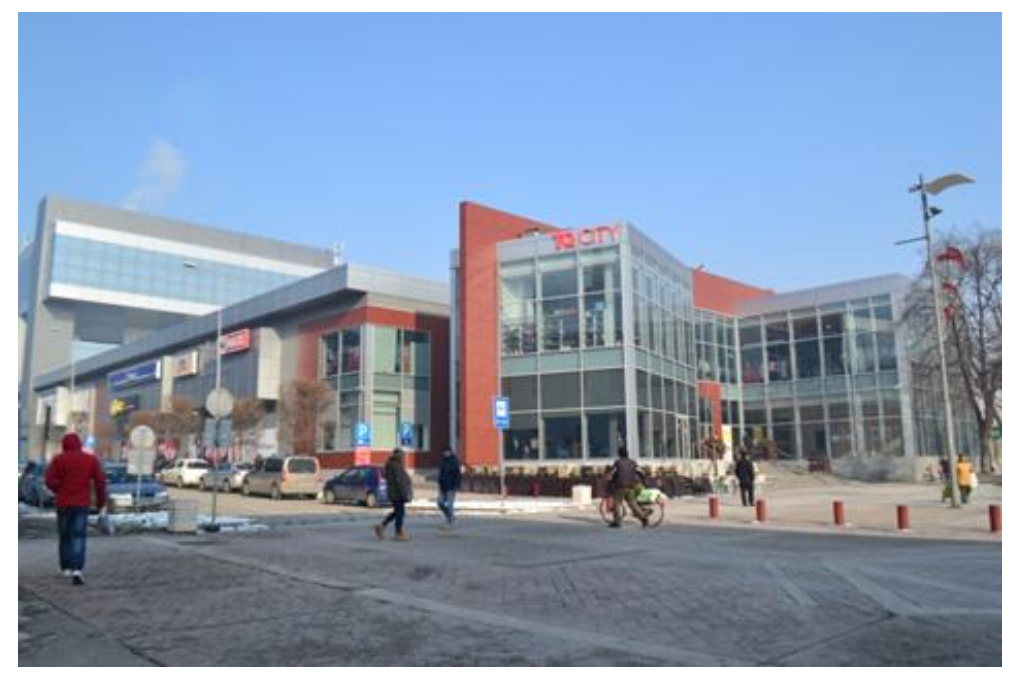

Figure 6: TQ City Mall. Source: author's archive

This property is located in the middle of Vojvode Stepe Street, which is the main promenade in the city. Together with the numerous service facilities located in this street (the section between Sloboda Mall and TQ City Mall), the city center was differentiated as an area designed mainly for shopping. In addition, post-socialist cities are characterized by street trade along major roads and blocks, as well as the arrival of the international sales chains. Objects of this kind can be found in the center of the city or in the driveways. Mixed-goods retail outlets are usually located near the city center (Fig. 15), while warehouses, building material shops, furniture and car salons are most often located along the access roads, starting the process of suburbanisation of commercial contents.

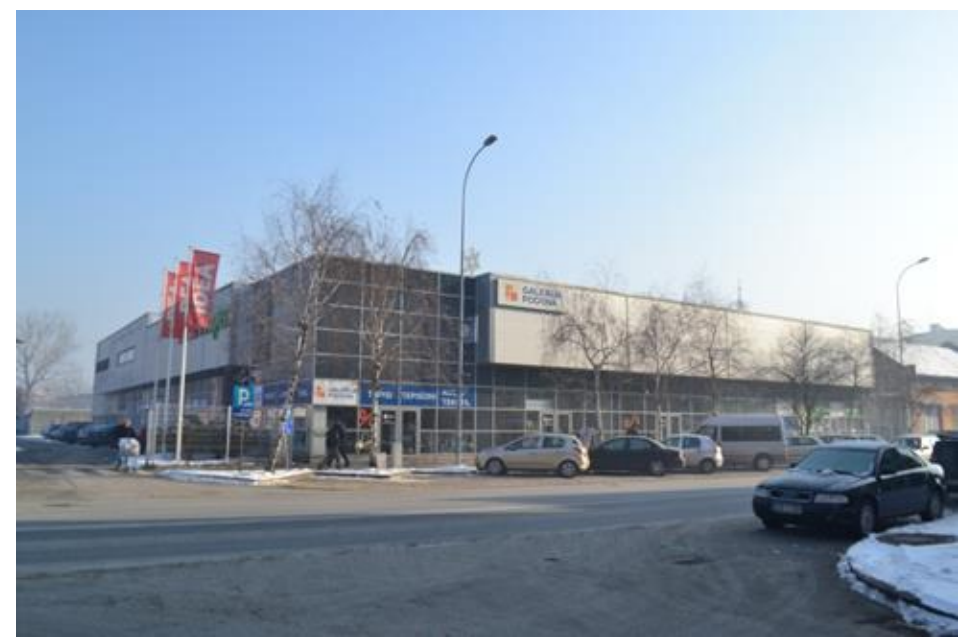

Figure 7: Idea megamarket on the road to Novi Sad. Source: author's archive.

Today, residential areas also represent very intensive construction areas. These are mostly collective housing buildings that are inserted between individual dwelling houses. It is a recognizable, contemporary type of construction, which is characteristic of all Serbian cities today. Often these are buildings that are being built in the shortest period of time, with minimal investment and numerous construction and infrastructure failures. Their aesthetics is often the subject of much discussion. All of this distorts the identity of this small town in Vojvodina, which was characterized by German houses of richly decorated facades. 


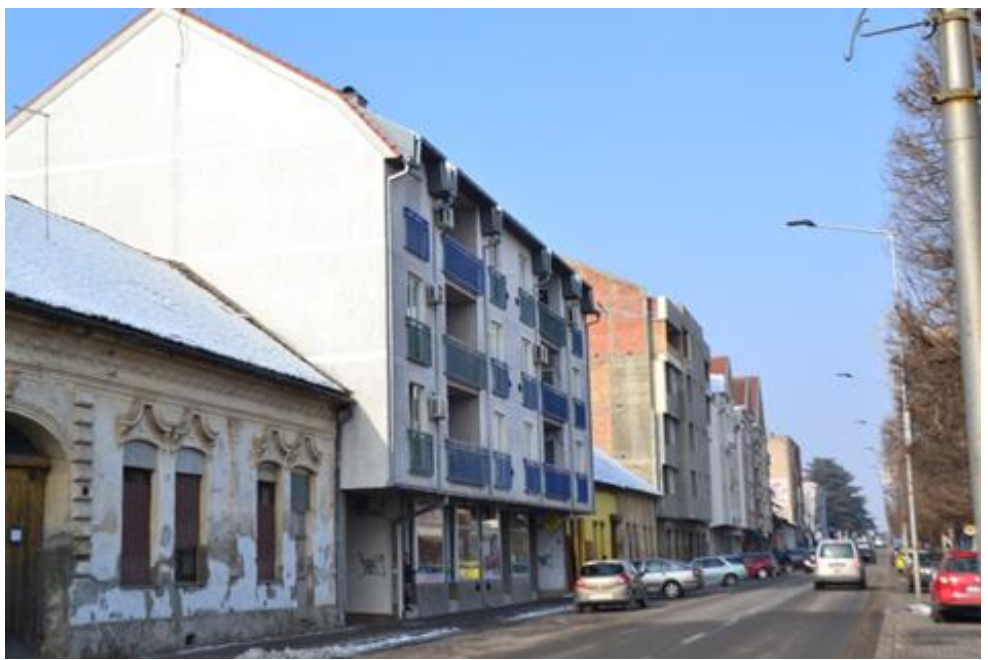

Figure 8: Contemporary construction in the central part of the city. Source: author's archive

When it comes to the housing area far from the city center, one can distinguish two zones. The first zone is the Šangaj settlement in the western part of the city, and the second zone is the Boško Buha settlement in the northern part of the city. These are also two zones in which Inđija is expanding its urban area. The Šangaj settlement is being more intensively built with the arrival of refugees from war-stricken areas of the SFRY during the 1990s. The houses are very spacious and richly decorated. In the northern part of the city, in the Boško Buha settlement, behind the city cemetery, identical houses can be seen.

Another feature of the transition period is the process of suburbanization. Although one cannot speak of the forms of suburbanization that have been achieved in the American suburbs, certain forms of spatial transformation are also evident in the suburbs of Inđija. Namely, at the entrance to Inđija from the direction of Novi Sad, the construction of magnificent houses and villas of interesting architectural solutions, with spacious and beautifully landscaped courtyards, can be seen lately. It can be concluded that the owners come from the wealthy class.

\section{CONCLUSION}

The urban core of Indija dates from the end of the 19th and the beginning of the 20th centuries, from the period of industrial development and the settlement of German people. After 1945, garden areas disappeared. They were replaced by new homes in new streets, garages, and craft workshops. After World War II, the first multi-family residential buildings in Inđija were built, in today's block no. 63 and along the main town road. Settlements were being expanded and new single-family housing zones were being formed as well as industrial zones. Also, new business and public facilities were being built. Since 1990, construction of office buildings and multi-family residential buildings has been intensified.

Over the last few years, Inđija has been developed and built at high speed. Foreign investors, attracted by the good location of the settlement, invest in this town and many factories are being opened. Industrial zones are being upgraded and industry is being developed. The city increasingly supports culture and education. Indija is one of the most developed municipalities in Serbia today, much invested in.

Spatial transformations have affected both the central parts of the city and the urban periphery. There was a transformation of residential into a commercial space, but also the 
construction of new, modern business premises. Single-family housing units in central parts of the city are increasingly being replaced by collective housing facilities, while at the same time the number of single-family housing units is being increased on the outskirts of the city.

The geo-traffic position of Inđija has exceptional benefits and a positive impact on its future urban development. The municipality of Inđija is located in the area of influence of the capital, Belgrade, as well as the macro-regional center of Novi Sad, which will continue to have an impact on its development. The available potentials for the development of the city of Inđija are the following: geo-traffic position, connectivity with the region and cities, market, facilities and investments, developed services and economy, built infrastructure, available industrial complexes and zones, natural resources, human resources and institutions.

Along with the assumptions of further development, problems and limitations for further urban development of Indija also arise. These problems relate to the review of the boundary of the construction zone of the settlement, i.e., the reduction of agricultural land in favor of construction land. The goal of industrial development is, in addition to the more dynamic development of existing industrial capacities, the development of new innovative high-tech activities (industrial-technological park), which will take advantage of the strategically important position of the municipality of Inđija while attracting investors, in accordance with environmental protection.

Assuming that a certain area for future housing construction will be provided in the existing housing zones, the reconstruction of the existing housing stock and construction of a new one should also provide large areas for new housing constructions. Due to all this, new spatial transformations can be expected in a town which, unlike most towns in Serbia, is intensively developing.

\section{REFERENCES}

[1] French, R. A. \& Hamilton, F. E. I. The Socialist City: Spatial Structure and Urban Policy. New York: John Wiley \& Sons, 1979.

[2] Szelenyi, I. Urban Development and Regional Management in Eastern Europe. Theory and Society, vol. 10, pp. 169-205. 1981.

[3] Szelenyi, I. Urban Inequalities Under State Socialism. Oxford: Oxford University Press, 1983.

[4] Musil, J. \& Ryšavy, Z. Urban and Regional Processes Under Capitalism and Socialism: A Case Study from Czechoslovakia. International Journal of Urban and Regional Research, vol. 7, pp. 495-527, 1983.

[5] Murray, P. \& Szelenyi, I. The City in the Transition to Socialism. International Journal of Urban and Regional Research, vol. 8, pp. 90-107, 1984.

[6] Dangschat, J. Sociospatial Disparities in a Socialist City: The Case of Warsaw at the End of the 1970s. International Journal of Urban and Regional Research, vol. 11, pp. 37-60, 1987.

[7] Hegedus, J. Reconsidering the Roles of the State and the Market in Socialist Housing Systems. International Journal of Urban and Regional Research, vol. 11, pp. 79-97, 1987.

[8] Musil, J. Housing Policy and the Sociospatial Structure of Cities in a Socialist Country: The Example of Prague. International Journal of Urban and Regional Research, vol. 11, pp. 27-36, 1987.

[9] Tosics, I. Privatization in Housing Policy: The Case of the Western Countries and That of Hungary. International Journal of Urban and Regional Research, vol. 11, pp. 61-78, 1987. 
[10] Tosics, I. Inequalities in East European Cities: Can Redistribution Ever Be Equalizing, and If So, Why Should We Avoid It? A Reply to Ivan Szelenyi. International Journal of Urban and Regional Research, vol. 12, pp. 133-136, 1988.

[11] Sjoberg, O. Shortage, Priority and Urban Growth: Towards a Theory of Urbanisation Under Central Planning. Urban Studies, vol. 36, pp. 2217-2236, 1999.

[12] Gentile, M. \& Sjoberg, O. Intra-urban Landscapes of Priority: The Soviet Legacy. EuropeAsia Studies, vol. 58, pp. 701-729, 2006.

[13] Hirt, S. Whatever Happened to the (Post)Socialist City? Cities, vol. 32, pp. S29-S38, 2013.

[14] Ferenčuhova, S. Accounts from Behind the Curtain: History and Geography in the Critical Analysis of Urban Theory. International Journal of Urban and Regional Research, vol. 40, pp. 113-131, 2016.

[15] Bernhardt, C. Planning Urbanization and Urban Growth in the Socialist Period: The Case of East-German Towns, 1945-1989. Journal of Urban History, vol. 32, no. 1, pp. 104-119, 2005.

[16] Hahn, T. \& Kahl, A. Urban Way of Life in the Advanced Socialist Society. Sociologický Časopis, vol. 18, pp. 34-48, 1982.

[17] Matějů, P. Development of the Socio-spatial Structure of Prague in the Years 1930-1970 in the Light of Factor Analysis. Sociologický Casopis, vol. 16, pp. 572-592, 1980.

[18] Osborn, R. J. \& Reiner, T. A. Soviet City Planning: Current Issues and Future Perspectives. Journal of the American Institute of Planners, vol. 28, pp. 239-250, 1962.

[19] Frolic, B. M. The Soviet City. Town Planning Review, vol. 34, pp. 285-300, 1964.

[20] Bater, J. H. Soviet Town Planning: Theory and Practice in the 1970s. Progress in Human Geography, vol. 1, pp. 177-207, 1977.

[21] Fisher, J. C. Planning the City of Socialist Man. Journal of the American Institute of Planners, vol. 28, pp. 251-265, 1962.

[22] Smith, D. M. The Socialist City, In Cities after Socialism: Urban and Regional Change and Conflict in Post-socialist Societies, edited by Gregory Andrusz, Michael Harloe, and Ivan Szelenyi, pp. 70-99. Oxford: Blackwell, 1996.

[23] Haussermann, H. From the Socialist to the Capitalist City: Experiences from Germany, In Cities After Socialism: Urban and Regional Change and Conflict in Post-socialist Societies, edited by Gregory Andrusz, Michael Harloe, and Ivan Szelenyi, pp. 214-231. Oxford: Blackwell, 1996.

[24] Sailer-Fliege, U. Characteristics of Post-socialist Urban Transformation in East Central Europe. GeoJournal, vol. 49, pp. 7-16, 1999.

[25] Hirt, S. Iron Curtains: Gates, Suburbs and Privatization of Space in the Post-socialist City. Malden: Wiley, 2012.

[26] Sykora, L. Post-socialist Cities, In International Encyclopedia of Human Geography. vol. 8, edited by Rob Kitchin and Nigel Thrift, pp. 387-395. Oxford: Elsevier, 2009.

[27] Velev, J. Gradski centri u procesu tranzicije, Beograd:,Zadužbina Andrejević, 2012.

[28] Costachie, S., Weckmüller, D. \& Lixandrescu, G. From Romania to Germany: A Complex Motivation of Post-Communist Ethnic Migration: Case Study: Germans of Romania. Zbornik radova Departmana za geografiju, turizam i hotelijerstvo, vol. 48, no. 2, pp. 143-159, 2019.

[29] Simson, F. \& Chapman, M. Comparison of urban governance and planning policy: East looking West. Cities, vol. 16, no. 5, pp. 353-364, 1999.

[30] Petrović, M. Gradovi u tranziciji: iskustva razvijenih zemalja u poslednjim decenijama 20. veka. Sociologija. vol. 42, no. 3, pp. 409-436, 2000. 
[31] Backović, V. Evropski gradovi u postsocijalističkoj transformaciji. Sociologija, vol. 47, no 1, pp. 27-44, 2005.

[32] Sikh, E. \& Wallace, C. The Development of Open-air Markets in East-Central Europe. International Journal of Urban and Regional Research, vol. 23, no. 4, pp. 697-714, 1999.

[33] Ćurčić, S. Naselja Srema, Novi Sad: Univerzitet u Novom Sadu, Prirodno-matematički fakultet, Departman za geografiju, turizam i hotelijerstvo, 2001.

[34] LER. Strategija lokalnog ekonomskog razvoja opštine Inđija 2014-2020, Inđija, 2014.

[35] Internet 1: https://fashionparkoutlet.rs/ Accessed on February 12, 2021.

[36] Internet 2: https://www.tradeunique.com/projects/tqvegas-indjja-serbia/ Accessed on February 12, 2021. 